\title{
Paleoparasitological results for rodent coprolites from Santa Cruz Province, Argentina
}

\author{
Norma Haydée Sardella1,4/+, Martín Horacio Fugassa ${ }^{1,4}$, Diego Damián Rindel ${ }^{2,4}$, \\ Rafael Agustín Goñi'i,3
}

\begin{abstract}
${ }^{1}$ Laboratorio de Paleoparasitología, Universidad Nacional de Mar Del Plata, Funes 3250, 7600 Mar del Plata, Argentina ${ }^{2}$ Instituto Nacional de Antropología y Pensamiento Latinoamericano, Buenos Aires, Argentina ${ }^{3}$ Universidad de Buenos Aires, Universidad Nacional del Centro de la Provincia de Buenos Aires, Buenos Aires, Argentina ${ }^{4}$ Consejo Nacional de Investigaciones Científicas y Técnicas, Buenos Aires, Argentina
\end{abstract}

The aim of this study was to examine the parasite remains present in rodent coprolites collected from the archaeological site Alero Destacamento Guardaparque (ADG) located in the Perito Moreno National Park (Santa

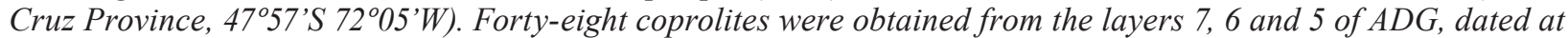
$6,700 \pm 70,4,900 \pm 70$ and 3,440 \pm 70 years $B P$, respectively. The faecal samples were processed and examined using paleoparasitological procedures. A total of 582 eggs of parasites were found in 47 coprolites. Samples were positive for eggs of Trichuris $s p$. (Nematoda: Trichuridae), Calodium $s p$., Eucoleus $s p$., Echinocoleus $s p$. and an unidentified capillariid (Nematoda: Capillariidae) and for eggs of Monoecocestus (Cestoda: Anoplocephalidae). Quantitative differences among layer for both coprolites and parasites were recorded. In this study, the specific filiations of parasites, their zoonotic importance, the rodent identity, on the basis of previous zooarchaeological knowledge, and the environmental conditions during the Holocene in the area are discussed.

Key words: paleoparasitology - helminths - rodents - Patagonia - nematodes - anoplocephalids - coprolites

Paleoparasitological studies carried out in Argentina are focused on the presence of parasite remains in coprolites, sediments and other materials, from camelids, carnivores, raptor birds, humans and rodents, recovered from Holocenic samples from Patagonia (Fugassa 2006, 2007, Fugassa \& Barberena 2006, Fugassa et al. 2006a, b, 2007a, b, 2008a, b, Sardella \& Fugassa 2009 a, b). Regarding rodents, their presence in the area seems to have been relevant because of the presence of their faeces, bones and hairs in all archaeological deposits examined at present and also by the finding of rodent remains and helminth eggs in coprolites of rodents and predators ( $\mathrm{Fu}$ gassa et al. 2006b, 2007b, Sardella \& Fugassa 2009 a, b).

One of the most important archaeological areas under study in Patagonia is the Perito Moreno National Park (PMNP), Santa Cruz Province, Argentina. It exhibits different sites, caves and shelters, with evidences of both human and animal occupations since the Pleistocene Holocene Transition to the Late Holocene (Aschero et al. 1992, 1993, 2005).

The increasing information recovered from other paleoparasitological sites at present, close to Cerro Casa de Piedra (CCP), contributes to enhance the discussion on issues such as the paleoecological biogeography of parasites in the region and the role of zoonoses in the caves and shelters of Patagonia during the Holocene.

Financial support: FONCyT, Universidad Nacional de Mar del Plata (PICT 06-1520, PICT 07-1576, EXA 438/08), CONICET

+ Corresponding author: sardella@mdp.edu.ar

Received 30 August 2009

Accepted 12 January 2010
The aim of the present study was to examine the parasite fauna present in rodent coprolites collected from one of these archaeological sites, the rock shelter Alero Destacamento Guardaparque (ADG). Since 1990 excavations were conducted in the area by archaeologists (Goñi et al. 1994, Goñi 1995, Rindel 2003, 2008), but none paleoparasitological antecedent exists at present.

\section{MATERIALS AND METHODS}

The archaeological site ADG is located in the PMNP (Santa Cruz Province, $47^{\circ} 57^{\prime} \mathrm{S} 72^{\circ} 05^{\prime} \mathrm{W}$ ), close to CCP (Fig. 1). It is a large shelter (250 m length) situated on a low hill oriented towards the southwest.

Forty-eight coprolites of rodents obtained from six samples from layers 7 ( 1 sample, $\mathrm{N}=8), 6$ ( 3 samples, $\mathrm{N}$ $=24)$ and $5(2$ samples, $\mathrm{N}=16)($ Fig. 2$)$, dated at 6,700 $\pm 70,4,900 \pm 70$ and $3,440 \pm 70$ years BP, respectively, were examined for parasites. Coprolites were inventoried and processed individually as described in Fugassa (2006). The examination consisted of the external observation of faeces (color, texture, inclusions and measurements) according to Chame (2003) and Jouy-Avantin (2003). Faecal macroscopic features and their average measurements are shown in Table I. Each coprolite was fully processed by rehydration in a $0.5 \%$ water solution of tris-sodium phosphate in a glass tube for a week; it was then homogenized and allowed to spontaneous sedimentation (Lutz 1919). The material that was sediment into the tube was recovered with a pipette and 10 slides of each sample were observed, with the addition of one drop of glycerine. Eggs of the parasites were measured and photographed at 40X magnification. Statistical analysis was performed using the package Biocistron: Bioestat 5.0 (Hotteling's test). 


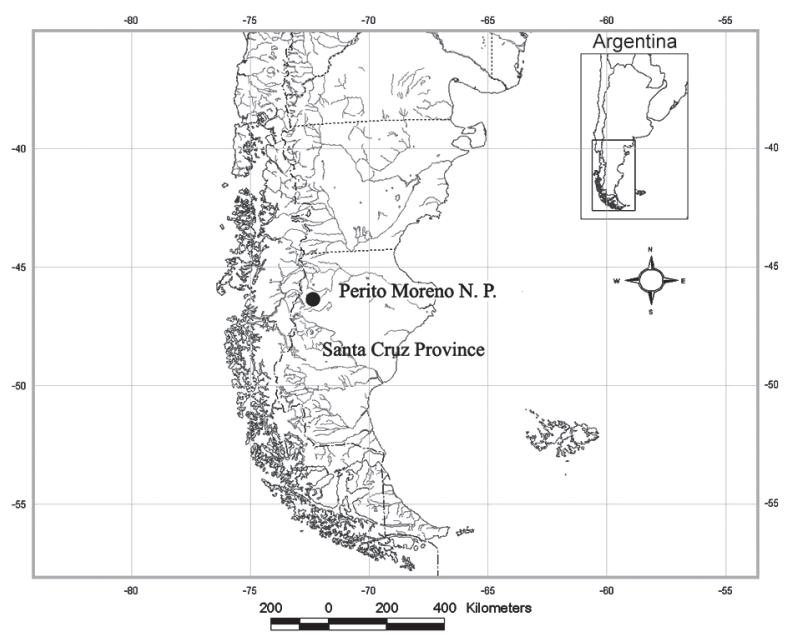

Fig. 1: geographic location of the archaeological site Alero Destacamento Guardaparque, Santa Cruz Province, Argentina.

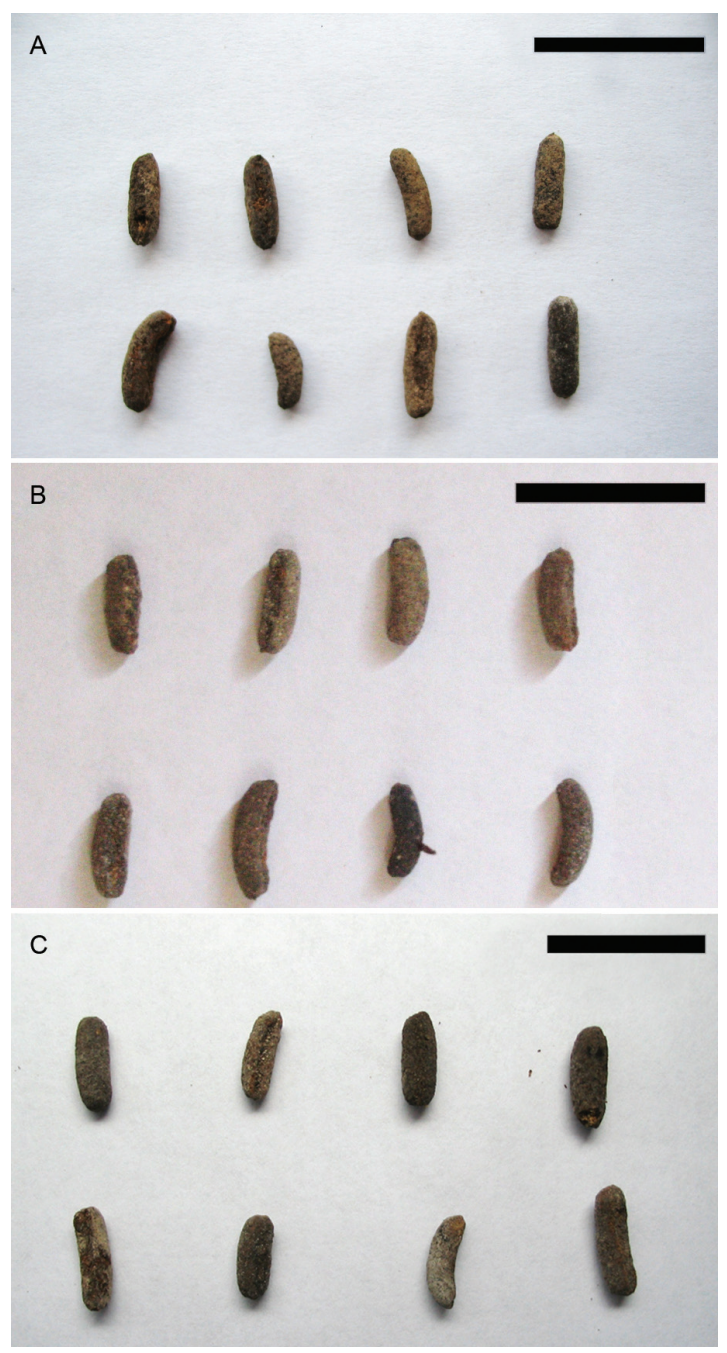

Fig. 2: macroscopic aspect of the coprolites examined from Alero Destacamento Guardaparque. A: from layer 7; B: from layer 6; C: from layer 5. Bars $=20 \mathrm{~mm}$.

\section{RESULTS}

Statistical comparisons showed that the coprolites from layers 7 vs. 6 (sample 1), from layer 6 (samples 2 vs. 3 ) and from layer 5 (sample 1 vs. 2) did not show significant differences $(\mathrm{p}=0.09 ; \mathrm{p}=0.61$ and $\mathrm{p}=0.06$, respectively). Nevertheless, measurements of the faeces from layer 6 (sample 1) vs. 6 (samples 2 plus 3 ) and 6 (samples 2 plus 3 ) vs. 5 (samples 1 plus 2 ) were statistically different ( $p=0.0001$ and 0.037 , respectively) (Table I). These results indicate that the coprolites examined came from different individuals and likely from different host species. Microscopic analysis of the faecal material revealed the presence of plant remains in all samples. The identity of rodents is unknown at present.

Of 48 coprolites, 47 were positive for Nematoda and/ or Cestoda. In total, 582 eggs were recovered from samples. The parasite contents were as follows: 178 eggs of a species of Trichuris Roederer (Nematoda: Trichuridae), 153 eggs with characteristics attributable to genus Calodium Dujardin, 56 eggs compatible with the genus $\mathrm{Eu}$ coleus Dujardin, 29 eggs of an unidentified capillariid, one egg attributable to Echinocoleus sp. López-Neyra (Nematoda: Capillariidae) and 165 eggs of Cestoda (Anoplocephalidae) with characteristics compatible with the genus Monoecocestus Beddard.

For Trichuris sp. (Fig. 3A), eggs were not ornamented and exhibited thick shells and plugs on each end. Average egg measurements from the six samples examined are shown in Table II. Significant statistical differences were found among eggs collected from the three layers and also within each layer. Egg measurements from layer 7 vs. 6 (sample 1) were different $(p=0.006)$ and also between layer 6 (sample 1) vs. 6 (sample 2 plus 3$)(p=$ 0.001). Among layer 6 (sample 2 plus 3 ) and 5 (sample 1 plus 2 ) were not found any difference $(\mathrm{p}=0.13$ and $\mathrm{p}=$ 0.38 , respectively), but between layers 6 and 5 , the differences were significant $(p=0.02)$. The identity of the eggs of Trichuris collected from ADG is unknown at present.

Eggs of capillariids attributable to the genera Calodium, Eucoleus and Echinocoleus and one unidentified capillariid were found in samples. They were recognized by the typical shape of the ornamented walls. For Calodium sp. (Fig. 3B), large eggs with shallow polar plugs and radial striations were collected. A total of 153 (layer $7, \mathrm{~N}=15$; layer $6, \mathrm{~N}=86$ and layer $5, \mathrm{~N}=52$ ) eggs was found in all coprolites examined and 97 of them were measured. Average egg measurements from the six samples examined were as follows: layer 7, 62.5-70 (65 \pm $2.89) \mu \mathrm{m}$ long by $33.75-45(39.11 \pm 3.44) \mu \mathrm{m}$ wide; layer 6: 57.5-75 (65.89 \pm 3.43$) \mu \mathrm{m}$ long by $35-45(39.19 \pm 2.45)$ $\mu \mathrm{m}$ wide and layer 5: 60-62.5 $(64.97 \pm 3.35) \mu \mathrm{m}$ long by $35-47.5(37.71 \pm 3) \mu \mathrm{m}$ wide. No significant differences were confirmed neither among eggs of Calodium collected from layers 7 and 6, nor within 5 (sample 1 plus 2). Nevertheless, egg measurements from layer 5 vs. 6 were different $(p=0.01)$. Based on the geographic area of the samples and the egg measurements, Calodium from layers 7 and 6 (sample 1) are overlapped and still larger than those reported for Calodium hepaticum (Bancroft) and likely belonged to new species. 
TABLE I

Rodent faeces features and average coprolite measurements by layers from Alero Destacamento Guardaparque

\begin{tabular}{|c|c|c|c|c|c|}
\hline & & $\begin{array}{l}\text { Length range } \\
\text { and mean } \\
(\mathrm{mm})\end{array}$ & $\begin{array}{l}\text { Width range } \\
\text { and mean } \\
(\mathrm{mm})\end{array}$ & $\begin{array}{l}\text { Weight range } \\
\text { and mean } \\
\text { (g) }\end{array}$ & $\begin{array}{l}\text { Significant statistical } \\
\text { differences } \\
(\mathrm{p}<0.05)\end{array}$ \\
\hline Layer 7 & $\begin{array}{l}(\mathrm{N}=8) \text { Gray to dark brown, } \\
\text { groove in the concave side, straight }\end{array}$ & $\begin{array}{c}9.9-13.4 \\
(11.73 \pm 2)\end{array}$ & $\begin{array}{c}3.3-4.6 \\
(3.86 \pm 0.44)\end{array}$ & $\begin{array}{c}0.028-0.068 \\
(0.044 \pm 0.01)\end{array}$ & - \\
\hline \multirow[t]{3}{*}{ Layer 6} & $\begin{array}{l}\text { Sample } 1(\mathrm{~N}=8) \text { Grayish brown, } \\
\text { groove in the concave side, with } \\
\text { whitish spots }\end{array}$ & $\begin{array}{c}10.1-12.9 \\
(11.72 \pm 0.82)\end{array}$ & $\begin{array}{c}3.8-5 \\
(4.26 \pm 0.40)\end{array}$ & $\begin{array}{c}0.042-0.081 \\
(0.057 \pm 0.01)\end{array}$ & $\begin{array}{c}\text { Layer } 6 \text { (sample } 1) \text { with sample } \\
2 \\
\text { plus } 3(\mathrm{p}=0.0001)\end{array}$ \\
\hline & $\begin{array}{l}\text { Sample } 2(\mathrm{~N}=8) \text { Brown, with } \\
\text { concave grooveon the side, straight }\end{array}$ & $\begin{array}{c}9.5-11.3 \\
(10.61 \pm 0.65)\end{array}$ & $\begin{array}{c}3-3.8 \\
(3.42 \pm 0.27)\end{array}$ & $\begin{array}{c}0.018-0.036 \\
(0.029 \pm 0.006)\end{array}$ & Layer 6 (sample 2 plus 3 ) \\
\hline & $\begin{array}{l}\text { Sample } 3(\mathrm{~N}=8) \text { grayishbrown, } \\
\text { white spots, groove, straight }\end{array}$ & $\begin{array}{c}8.7-11.9 \\
(10.86 \pm 1)\end{array}$ & $\begin{array}{c}2.8-3.6 \\
(3.27 \pm 0.29)\end{array}$ & $\begin{array}{c}0.027-0.044 \\
(0.031 \pm 0.005)\end{array}$ & $\begin{array}{l}\text { with layer } 5 \text { (sample } 1 \text { plus } 2) \\
\qquad(p=0.037)\end{array}$ \\
\hline \multirow[t]{2}{*}{ Layer 5} & $\begin{array}{l}\text { Sample } 1(\mathrm{~N}=8) \text { dark grayish } \\
\text { brown, whitish spots, } \\
\text { concave groove }\end{array}$ & $\begin{array}{c}10.1-14.2 \\
(11.62 \pm 1.49)\end{array}$ & $\begin{array}{c}3.7-4.6 \\
(4.07 \pm 0.36)\end{array}$ & $\begin{array}{c}0.028-0.068 \\
(0.044 \pm 0.01)\end{array}$ & $\begin{array}{c}\text { Layer } 5 \text { (sample } 1 \text { plus } 2) \\
\text { with layer } 6 \text { (sample } 2 \text { plus } 3 \text { ) }\end{array}$ \\
\hline & $\begin{array}{l}\text { Sample } 2(\mathrm{~N}=8) \text { brownish gray, } \\
\text { one side flat, straight }\end{array}$ & $\begin{array}{c}9.3-12.5 \\
(10.96 \pm 0.92)\end{array}$ & $\begin{array}{c}3-3.7 \\
(3.5 \pm 0.26)\end{array}$ & $\begin{array}{l}0.025-0.048 \\
\quad(0.034)\end{array}$ & \\
\hline
\end{tabular}
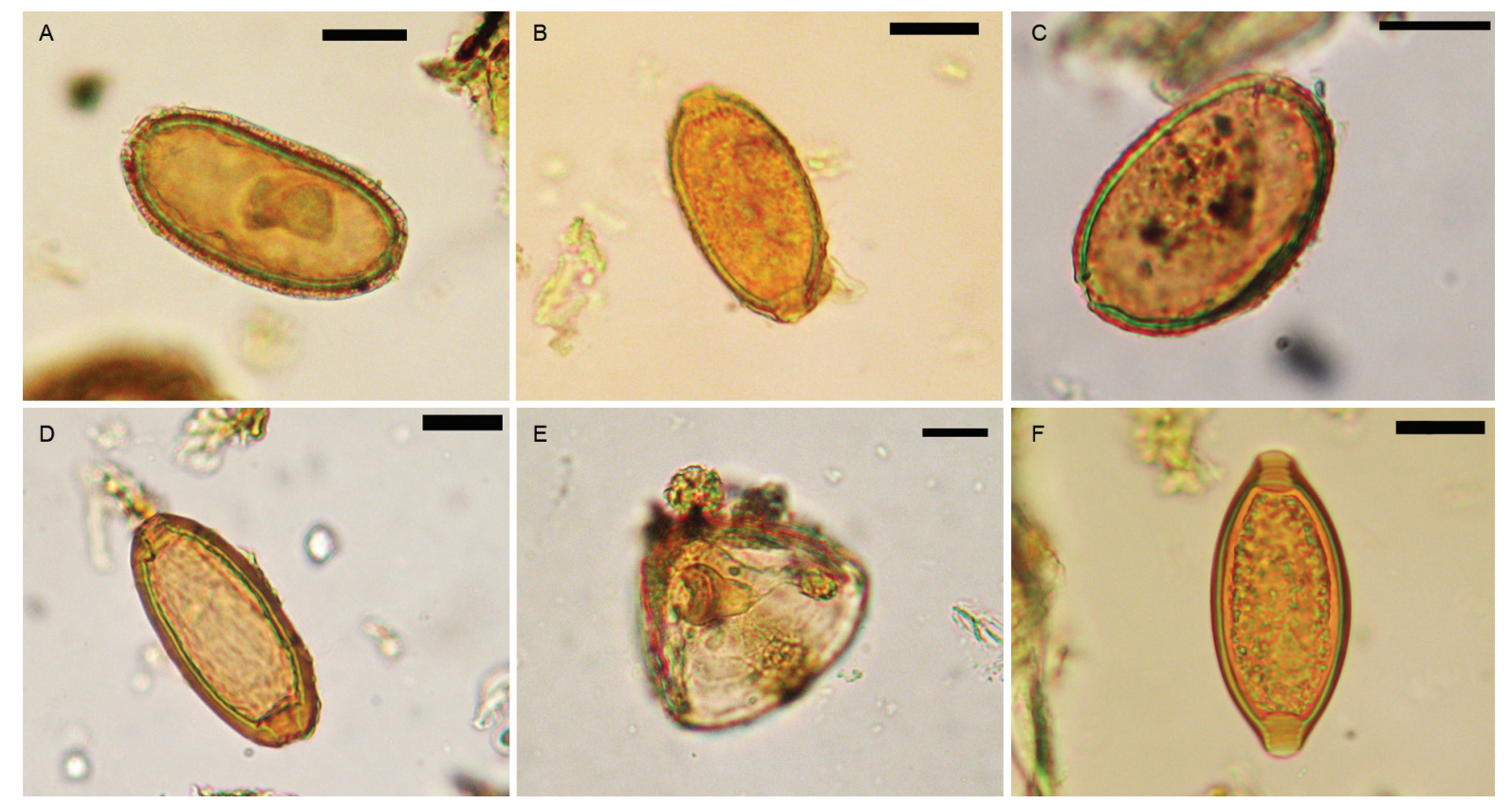

Fig. 3: A: egg of Trichuris sp.; B: egg of Calodium sp.; C: egg of Eucoleus sp.; D: egg of unidentified capilariid; E: egg of Echinocoleus sp.; F: egg of Monoecocestus sp. Bars $=20 \mu \mathrm{m}$.

Eggs attributable to Eucoleus sp. $(\mathrm{N}=85)$ (Fig. $3 \mathrm{C})$, with irregular striations and short plugs, 50-55 (52.08 \pm 2.79) $\mu \mathrm{m}$ long by $22.5-35(26.61 \pm 2.28) \mu \mathrm{m}$ wide, were collected from the three layers $(\mathrm{N}=16,33$ and 7, respectively). Another capillariid eggs $(\mathrm{N}=29)$ (Fig. $3 \mathrm{D})$ unidentified at present, with pitted surface, 55-67.5 (61.76 \pm 3.29) $\mu \mathrm{m}$ long by 32.5-42.5 (37.21 \pm 2.61$) \mu \mathrm{m}$ wide were found, 19 of them recovered from layer 6 (sample 1, N
$=14$, sample $2, \mathrm{~N}=4$ and sample $3, \mathrm{~N}=1)$ and 10 eggs from layer $5(\mathrm{~N}=7$ from sample 1 and $\mathrm{N}=3$ from sample 2). For both capillariids, no significant differences among layer were registered.

Additionally, only one egg compatible with Echinocoleus sp. $(65 \mu \mathrm{m}$ by $31.5 \mu \mathrm{m})$ was found from layer 5 (sample 2) (Fig 3E). The surface of the wall of this egg exhibited grooves. 
TABLE II

Average measurements of eggs of Trichuris spp and significant statistical differences by layers from Alero Destacamento Guardaparque

\begin{tabular}{|c|c|c|c|c|}
\hline \multicolumn{2}{|c|}{ Total number of eggs/eggs measured } & $\begin{array}{l}\text { Length range } \\
\text { and mean } \\
(\mu \mathrm{m})\end{array}$ & $\begin{array}{l}\text { Width range } \\
\text { and mean } \\
(\mu \mathrm{m})\end{array}$ & $\begin{array}{c}\text { Statistical } \\
\text { differences } \\
(\mathrm{p}<0.05)\end{array}$ \\
\hline \multicolumn{2}{|l|}{$\begin{array}{l}\text { Layer } 7 \\
(\mathrm{~N}=84 / 55)\end{array}$} & $\begin{array}{c}61.25-70 \\
(65.41 \pm 1.93)\end{array}$ & $\begin{array}{c}30-32.5 \\
(31.57 \pm 1.28)\end{array}$ & \multirow{4}{*}{$\begin{array}{c}\text { With layer } 6 \\
\quad(\mathrm{p}=0.006) \\
\text { With layer } 7(\mathrm{p}=0.006) \\
\text { layer } 6(\text { sample } 1) \mathrm{vs} . \\
\text { layer } 6(\text { sample } 2 \text { plus } 3) \\
\quad(\mathrm{p}=0.001) \\
\text { layer } 5(\mathrm{p}=0.02)\end{array}$} \\
\hline \multirow[t]{3}{*}{$\begin{array}{l}\text { Layer } 6 \\
(\mathrm{~N}=75 / 49)\end{array}$} & $\begin{array}{c}\text { Sample } 1 \\
(\mathrm{~N}=54 / 33)\end{array}$ & $\begin{array}{c}60-70 \\
(63.82 \pm 1.89)\end{array}$ & $\begin{array}{c}30-33.75 \\
(32.23 \pm 0.87)\end{array}$ & \\
\hline & $\begin{array}{c}\text { Sample } 2 \\
(\mathrm{~N}=16 / 12)\end{array}$ & $\begin{array}{c}57.5-65 \\
(61.97 \pm 1.95)\end{array}$ & $\begin{array}{c}30-35 \\
(32.19 \pm 1.32)\end{array}$ & \\
\hline & $\begin{array}{l}\text { Sample } 3 \\
(\mathrm{~N}=5 / 4)\end{array}$ & $\begin{array}{c}60-62.5 \\
(60.62 \pm 1.25)\end{array}$ & $\begin{array}{c}30-33.75 \\
(32.19 \pm 1.57)\end{array}$ & \\
\hline \multirow[t]{2}{*}{$\begin{array}{l}\text { Layer } 5 \\
(\mathrm{~N}=19 / 13)\end{array}$} & $\begin{array}{c}\text { Sample } 1 \\
(\mathrm{~N}=11 / 7)\end{array}$ & $\begin{array}{c}60-67.5 \\
(64.46 \pm 2.48)\end{array}$ & $\begin{array}{c}30-35 \\
(32.14 \pm 2.25)\end{array}$ & \multirow[t]{2}{*}{$\begin{array}{c}\text { With layer } 6 \\
(\mathrm{p}=0.02)\end{array}$} \\
\hline & $\begin{array}{c}\text { Sample } 2 \\
(\mathrm{~N}=8 / 6)\end{array}$ & $\begin{array}{c}60-67.5 \\
(63.75 \pm 2.62)\end{array}$ & $\begin{array}{c}30-32.5 \\
(30.83 \pm 1.29)\end{array}$ & \\
\hline
\end{tabular}

A total of 165 eggs of Cestoda (order Cyclophyllidea, family Anoplocephalidae), with features attributable to genus Monoecocestus, was found (Fig. 3F) from the three layers, with exception of sample 1, from both layers 6 and 5. Egg measurements are shown in Table III. Eggs were statistically different among the three layers $(\mathrm{p}<0.05)$.

Microscopic remains of rodent hairs, unidentified insect appendages and mites were also discovered in the coprolites.

\section{DISCUSSION}

It was not currently possible to identify the specific biological origin of the rodent coprolites examined. Rindel $(2003,2008)$ stated that the dominant components of the rodent communities in ADG were Euneomys chinchilloides, Ctenomys sp. and Reithrodon auritus (94\%, 93\% and 74\% from layers 7, 6 and 5, respectively) and in much lesser proportions were present Abrothrix longipilis, Abrothrix xantorhynus, Loxodontomys micropus, Phyllotis xantophyga, Chelemys macronyx, Eligmodontia sp. and Oligoryzomys longicaudatus. Pardiñas and Galliari (2001) noticed that faeces from $R$. auritus and Euneomys are similar, but those from $R$. auritus have one end acuminate, unlike those of Euneomys. It is possible that some coprolites examined in the present study belonged to E. chinchilloides or to Ctenomys sp. (without acuminate ends). Redford and Eisenberg (1992) also cited that $E$. chinchilloides was a dominant species at the end of the Pleistocene, as evidenced by owl pellets contents. The significant differences found in this study among the measurement of faeces collected from the three layers of ADG, could be indicative of the presence of more than one rodent host species in samples.

The sites corresponding to the Early Holocene in PMNP are mostly located south of Río Roble. However, a feature that is of interest in ADG, is that despite be- ing in the northern area of Río Roble, the site harbored occupations in early (with contemporary CCP5), as in late stages (Rindel 2003, 2008). One of the assumptions made for the area raises the possible complement functionality between the caves located in the southern sector of PMNP (CCP5 and CCP7) and ADG, for the Early to Medium Holocene. Layer 6 provides chronologies of comparable occupations in CCP5 and CCP7. ADG has been proposed to function as a satellite site of $\mathrm{CCP}$, with limited activities in the rock shelter and numerous activities in the caves (Aschero et al. 1992, 1993, 2005).

With respect to the parasites found in samples, it is known that Trichuris spp are parasites of the caecum and colon of mammals of several orders (Anderson 2000). There are many studies on their biology, but little is known about their origin and host's preferences (Robles 2008). In America there were identified 21 species of Trichuris in nine rodent families, with five species found in Argentina, Trichuris dolichotis Morini, Boero and Rodriguez, parasite of Dolichotis patagonum (Zimmermann) (Morini et al. 1955), Trichuris laevitestis Suriano et Navone, parasite of Scapteromys aquaticus Thomas and Akodon azarae (Fischer) (Suriano \& Navone 1994, Robles \& Navone 2006); Trichuris bursacaudata Suriano et Navone, parasite of Ctenomys talarum Thomas (Suriano \& Navone 1994); Trichuris pampeana Suriano et Navone parasitic on Ctenomys azarae Thomas (Suriano \& Navone 1994, Rossin \& Malizia 2005) and Trichuris pardinasi Robles, Navone et Notarnicola parasite of Phyllotis xanthopyga (Waterhouse) (Robles et al. 2006, Robles 2008).

Reports of Trichuris spp in South American rodents from ancient material are those of Ferreira et al. (1991), Araújo et al. (1993), Fugassa (2006) and Sardella and Fugassa (2009a, b), among others. Because of the overlap in the egg dimensions for Trichuris spp infecting 
TABLE III

Average measurements of eggs of Monoecocestus spp by layers from Alero Destacamento Guardaparque

\begin{tabular}{|c|c|c|c|c|}
\hline \multicolumn{2}{|c|}{ Total number of eggs/eggs measured } & $\begin{array}{l}\text { Length range } \\
\text { and mean } \\
(\mu \mathrm{m})\end{array}$ & $\begin{array}{l}\text { Width range } \\
\text { and mean } \\
\quad(\mu \mathrm{m})\end{array}$ & $\begin{array}{c}\text { Significant statistical } \\
\text { differences } \\
(\mathrm{p}<0.05)\end{array}$ \\
\hline \multicolumn{2}{|l|}{$\begin{array}{l}\text { Layer } 7 \\
(\mathrm{~N}=36 / 22)\end{array}$} & $\begin{array}{c}57.5-70 \\
(63.09 \pm 3.19)\end{array}$ & $\begin{array}{c}60-70 \\
(65.23 \pm 2.98)\end{array}$ & $\begin{array}{l}\text { With layer } 5 \\
(\mathrm{p}=0.003)\end{array}$ \\
\hline \multirow[t]{3}{*}{$\begin{array}{l}\text { Layer } 6 \\
(\mathrm{~N}=64 / 32)\end{array}$} & Sample $1=\mathrm{NP}$ & & & \multirow{3}{*}{$\begin{array}{c}\text { Layer } 6 \text { (sample } 2) \text { vs. } \\
\text { layer } 6 \\
(\text { sample } 3) \\
(\mathrm{p}=0.0006)\end{array}$} \\
\hline & Sample $2(\mathrm{~N}=58 / 26)$ & $\begin{array}{c}48.75-65 \\
(55.91 \pm 4.55)\end{array}$ & $\begin{array}{c}50-70 \\
(56.63 \pm 4.95)\end{array}$ & \\
\hline & Sample $3(N=6 / 6)$ & $\begin{array}{c}60-72.5 \\
(65.42 \pm 5.34)\end{array}$ & $\begin{array}{c}55-75 \\
(64.58 \pm 6.78)\end{array}$ & \\
\hline \multirow{2}{*}{$\begin{array}{l}\text { Layer } 5 \\
(\mathrm{~N}=65 / 26)\end{array}$} & Sample 1 (no parasites found) & & & \multirow{2}{*}{$\begin{array}{l}\text { With layer } 7 \\
(\mathrm{p}=0.0003)\end{array}$} \\
\hline & Sample $2(\mathrm{~N}=65 / 26)$ & $\begin{array}{c}57.5-67.5 \\
(63.65 \pm 3.26)\end{array}$ & $\begin{array}{c}47.5-65 \\
(58.56 \pm 5.20)\end{array}$ & \\
\hline
\end{tabular}

rodents, not only in Argentina, but also in Chile, as is the case for Trichuris bradleyi, Trichuris chilensis, Trichuris fulvi and Trichuris robusti (Babero et al. 1975, 1976, Babero \& Murúa 1987, 1990), the parasites found in ADG were, therefore, assigned to more than one species of Trichuris. In this sense, there were differences in the archaeofaunistic composition among the layers in ADG, showing different percentages in the rodent composition of communities throughout the studied period (Rindel 2003, 2008).

Based on the geographic area of the samples and the egg measurements, eggs of Trichuris from layers 7 and 6 (sample 1) are within the range of those reported for T. bursacaudata (Suriano \& Navone 1994). Trichuris from layer 6 (sample 2 plus 3) corresponds to T. bradleyi (Babero et al. 1975, 1976, Babero \& Murúa 1987, 1990) and Trichuris from layer 5 is within the range of Trichuris sp. (layer 13 from CCP7, dated at 7,920 \pm 130 yr BP) (Sardella \& Fugassa 2009b), or they also could be new species, not yet described for the studied area.

Some authors argue that Trichuris is not present in extreme latitudes, low temperatures being the main limiting factor (Nolf 1932) and that the areas around the tropics (warm and humid) would offer more favorable conditions for the development and survival of various parasites (Bundy \& Cooper 1989). Nevertheless, the presence of Trichuris in ADG and from all the archaeological sites examined from Patagonia at present, help to doubt those assumptions.

Classification of Capillariidae is one of the most complexes among nematodes (Anderson 2000). The family is composed of 22 genera and 300 species (Anderson 2000, Moravec 2000, 2001). In America, 16 species of Capillaridae are known as parasites of 10 families of mammals, four of them are parasites of rodents of the families Cricetidae, Muridae, Cavidae and Sciuridae (Robles 2008). In Argentina, Eucoleus gastricus (Baylis) was reported as the parasite of Rattus norvegicus (Berkenhout) (LópezNeyra 1947, in Robles 2008). Robles (2008) consigned that in sigmodontine rodents, three species of Capillariidae with distribution in North America, C. hepaticum, E. gastricus and Aonchotheca forresteri (Kinsella et Pence) were recognized. Robles (2008) found Eucoleus sp. and Echinocoleus sp. in Akodontini rodents from Cuenca del Plata, Buenos Aires Province.

Paleoparasitological records of capillariids indicate their ubiquitous presence in several samples and from different archaeological sites (Fugassa 2006, 2007, Fugassa \& Barberena 2006, Fugassa et al. 2006a, b, 2007a, b, 2008a, b, Sardella \& Fugassa 2009 a, b). The presence of eggs attributable to Calodium sp., Eucoleus sp. and Echinocoleus sp. adds the rock shelter ADG to the previous records.

In relation to Calodium, egg measurements are in line and still larger than the eggs of $C$. hepaticum. Moreover, the life-cycle of $C$. hepaticum assumes the appearance of little or no egg in faeces. There are major limitations in identifying specimens of Capillaria sensu lato to species level. Zhu et al. (2000), using mitochondrial DNA analysis within and among species of Capillaria s. $l$. from Australian marsupials and rodents, cited that, although highly variable in their host and tissue specificity, they may exhibit the greatest degree of specificity at the level of host genus. This argument, together with the differences in measurements found, allow to state that the eggs of capillariids examined from ADG could belong to new species, not yet described for the area.

The genus Eucoleus is currently distributed in America, Europe, Oceania and Asia and includes 30 species parasitizing the respiratory organs, oral cavity, tongue, oesophagus and stomach of birds and mammals (Moravec 2001). Robles (2008) found 2 species of $E u$ coleus from the stomach of two species of cricetids collected from North of Argentina. Respect to the paleopar- 
asitological records of this parasite genus, Sardella and Fugassa (2009b) found eggs in coprolites of Ctenomys sp. from CCP7 and in this study, the presence of Eucoleus sp. was confirmed throughout all the Holocenic period of time considered, present in the three layers.

The genus Echinocoleus is currently distributed in America, Asia and Oceania and comprises six species parasitizing the intestine of birds and mammals (Moravec 2001). The first communication of the presence of this genus in Argentina was that of Robles (2008), who found Echinocoleus sp. from one cricetid from Buenos Aires province. The finding of only one egg of this nematode in the present study was probably due to a low parasitic load or taphonomic processes.

Anoplocephalidae cestodes are represented by 25 genera in small mammals (Wickström et al. 2005). Intermediate hosts are oribatid mites ingested by their herbivorous definitive hosts (Beveridge 1994). Rego (1961) reviewed the genus Monoecocestus, recording several species from rodents living in Brazil, Paraguay, Perú and Chile. In Argentina, Sutton (1973) described the species Monoecocestus myopotami, in the otter Myocastor coypus. The only previous paleoparasitological record of this genus in rodents was from coprolites from the historical site Alero Mazquiarán (Sardella \& Fugassa 2009a). Eggs of Monoecocestus found in the present study from ADG probably belonged to different species, because they exhibited significant differences among layers.

It should be noted that all the parasitic representatives of the genera found in this study are currently known as zoonotic. Perkins et al. (2005) stated that rodents represent one of the most important sources of zoonoses for mammals and that the increasing density of rodents forced their dispersion to occur and brought them into closer contact with humans.

Species of Trichuris are included among the zoonotic geohelminths (Wong \& Bundy 1990), since infection involves ingestion of contaminated soils. Bundy \& Cooper (1989) stated that gastrointestinal helminthosis is estimated to be the most common of all parasitic infections, with more than a quarter of the world's population infected with four human nematode species, Trichuris trichiura Linnaeus occupying the second order of importance, after Ascaris lumbricoides Linnaeus. The zoonotic potential of Trichuris was also documented for Trichuris vulpis, parasite of dog worldwide (Singh et al. 1993, Dunn et al. 2002). It is probable that Trichuris spp of Patagonic rodents in ADG could be infectious for humans, because during the Holocene, humans and animals shared caves and shelters.

Capillariidae exhibit both direct and indirect cycles, a vertebrate being the definitive host. In the case of heteroxenic cycles, the intermediate host ingests the eggs and the infective larvae develop in it (Anderson 2000, Morand et al. 2006). The life-cycle of $C$. hepaticum requires rodent death, ingestion and digestion of infected liver and then deposition of unembryonated eggs in the environment, which will allow them to survive and embryonate; mice are thought to become infected through ingestion of embryonated eggs (Singleton et al. 1991). Reports of human infections with C. hepaticum in different parts of the world could indicate that infection is more common in humans than supposed and the majority of proven infections have ended fatally (FarhangAzad \& Schlitter 1978). It is unlikely that Calodium spp found in rodent coprolites from ADG was C. hepaticum. However, it seems likely that other capillariid parasites of rodents, not only $C$. hepaticum, may have potentially caused disease, because of the close contact of humans with rodents in the Holocenic caves and shelters.

The life cycle of Eucoleus aerophilus is not well known at present, but it appears to involve direct transmission, as well as indirect transmission through earthworms, to canids, felids and foxes (Radman et al. 1986, Burguess et al. 2008). In relation to the hazards to humans, Eucoleus sp. has been reported as a human parasite in seven cases in Russia, one in Morocco, one in Iran and one in Ukraine (Beaver et al. 1984, in Bowman et al. 2002). The most common signs were acute bronchitis and broncheolitis, usually with asthma and cough. Despite eggs found in ADG could not be identified at specific level, the role of Eucoleus sp. as possible causative of illness to humans could not be discarded.

Knowledge of Echinocoleus life cycle and pathogeny is limited, because considerations on its zoonotic importance are inexistent in bibliography at present. Moravec (2001) stated that, of 22 present valid genera of capillariids, the life cycle has been studied in members of only 10 genera and that there are not data in this sense concerning the genus Echinocoleus.

Anoplocephalids can cause human disease when humans eat mites present in the soil (Denegri et al. 1998). Humans living in ADG were probably exposed to illness by Monoecocestus spp during all the period of time considered.

The knowledge of the climatic conditions prevalent in the area during the Early to Medium Holocene has conducted studies on the environmental conditions during the period in Patagonia (Stine \& Stine 1990). The sequence in the Patagonian climate was similar throughout the Holocene, with a trend toward aridity since the Middle Holocene. However, the information generated by different lines of research on a regional scale, suggests substantial fluctuations in climate and landscape to be considered in the reconstruction of settlement and mobility strategies of hunter-gatherer populations. One source of information available was studied from the Lago Cardiel, $110 \mathrm{~km}$ SE of ADG. Stine and Stine (1990) indicate significant variations in the level of the lake in the Holocene, alternating dry periods with episodes of elevation of the moisture. These authors identified peaks of the lake height between 10,000-7,000 years BP, then between 5,500-4,500 years BP. Subsequently, these levels were never reached again, alternating periods of very low humidity with some increases.

Another kind of paleoenvironmental information proceeded from the pollen studies carried out in the area, showing the alternation between the shrubland and herbaceous steppe, as well as the variability registered in the extent of Nothofagus forest, over the past 7,000 years (Mancini et al. 2002). The analysis suggests that in environments such as the mosaic of the study area, plant communities react sensitively and rapidly to extreme climatic oscillations. 
The study presented here suggests that, sites of habitual occupation by Patagonian hunters such as caves and shelters, could have acted as potential environments for transmission of various types of parasites, as those identified here. Under these conditions, the study of lines of paleoparasitological evidence is presented as an important source of information about the relationships that the Patagonian hunter-gatherer groups established with the environment, information that can be combined in future with other disciplines, such as the zooarchaeology and bioarchaelogy, in order to obtain a better picture of the lives and health of past human groups.

\section{REFERENCES}

Anderson RC 2000. Nematode parasites of vertebrates: their development and transmission, CAB International, Wallingford, $650 \mathrm{pp}$.

Araújo A, Rangel A, Ferreira LF 1993. Climatic change in Northern Brazil - Paleoparasitological data. Mem Inst Oswaldo Cruz 88: 577-579.

Aschero CA, Bellelli C, Goñi RA 1992, 1993. Avances en las investigaciones arqueológicas del Parque Nacional Perito Moreno (Provincia de Santa Cruz, Patagonia Argentina). Cuad Inst Nac Antrop Pens Lat 14: 143-167.

Aschero CA, Goñi RA, Civalero MT, Molinari R, Espinosa SL, Guraieb AG, Bellelli C 2005. Holocenic Park: arqueología del Parque Nacional Perito Moreno. An Adm Parq Nac 17: 71-119.

Babero BB, Murúa R 1987. The helminth fauna of Chile. X. A new species of whipworm from a Chilean rodent. Trans Am Microsc Soc 106: 190-193.

Babero BB, Murúa R 1990. A new species of whipworm from South American hystricomorph rodent. Mem Inst Oswaldo Cruz 85: 211-213.

Babero P, Cattán E, Cabello C 1975. Trichuris bradleyi sp. n., a whipworm from Octodon degus in Chile. J Parasitol 61: 1061-1063.

Babero P, Cattán E, Cabello C 1976. A new species of whipworm from the rodent Akodon longipilis in Chile. Trans Am Microbiol Soc 95: 232-235.

Beveridge I 1994. Family Anoplocephalidae Cholodkovsky, 1902. In LF Khalil, A Jones, RA Bray, Key to the Cestode parasites of vertebrates, $\mathrm{CAB}$ International, Wallingford, p. 315-366.

Bowman DD, Hendrix CM, Lindsay DS, Barr SC 2002. Feline clinical parasitology. Wiley-Blackwell, $469 \mathrm{pp}$.

Bundy DAP, Cooper ES 1989. Trichuris and trichuriasis in humans. Adv Parasitol 28: 107-173.

Burgess H, Ruotsalo K, Peregrine AS, Hanselman B, Abrams-Ogg A 2008. Eucoleus aerophilus respiratory infection in a dog with Addison's disease. Can Vet J 49: 389-392.

Chame M 2003. Terrestrial mammal feces: a morphometric summary and description. Mem Inst Oswaldo Cruz 98: 71-94.

Denegri G, Bernardina W, Pérez-Serrano J, Rodríguez Caabeiro F 1998. Anoplocephalidae cestodes of veterinary and medical significance: a review. Folia Parasitol 45: 1-8.

Dunn JJ, Columbus ST, Aldeen WE, Davis M, Carroll KC 2002. Trichuris vulpis recovered from a patient with chronic diarrhea and five dogs. J Clin Microbiol 40: 2703-2704.

Farhang-Azad A, Schlitter DA 1978. Capillaria hepatica in small mammals collected from Shoa Province, Ethiopia. J Wildl Dis 14: 358-361.
Ferreira LF, Araújo A, Confalonieri U, Chame M, Gomes DC 1991. Trichuris eggs in animal coprolites dated from 30,000 years ago. J Parasitol 77: 491-493.

Fugassa MH 2006. Enteroparasitosis en poblaciones cazadoras-recolectoras de Patagonia Austral, PhD Thesis, Universidad Nacional de Mar del Plata, Mar del Plata, 276 pp.

Fugassa MH 2007. Camélidos, parásitos y ocupaciones humanas: registros paleoparasitológicos en Cerro Casa de Piedra 7 (Parque Nacional Perito Moreno, Santa Cruz, Argentina. Intersec Antropol 8: 265-269.

Fugassa MH, Araújo A, Guichón RA 2006a. Quantitative paleoparasitology applied to archaeological sediments. Mem Inst Oswaldo Cruz 101: 29-33.

Fugassa MH, Araújo A, Sardella N, Denegri GM 2007a. New paleoparasitological finding in caves from Patagonia, Argentina. Paleopathol Newsl 137: 17-21.

Fugassa MH, Barberena R 2006. Cuevas y zoonosis antiguas: paleoparasitología del sitio Orejas de Burro 1 (Santa Cruz, Argentina). Magallania 34: 57-62.

Fugassa MH, Denegri GM, Sardella NH, Araújo A, Guichón RA, Martínez PA, Civalero MT, Aschero C 2006b. Paleoparasitological records in canid coprolite from Patagonia, Argentina. J Parasitol 92: 1110-1111.

Fugassa MH, Sardella NH, Denegri GM 2007b. Paleoparasitological analysis of a raptor pellet from Southern Patagonia. J Parasitol 93: 421-422.

Fugassa MH, Sardella NH, Guichón RA, Denegri GM, Araújo A 2008a. Paleoparasitological analysis applied to museum-curated sacra from meridional Patagonian collections. J Archaeol Sci 35: 1408-1411.

Fugassa MH, Taglioretti V, Gonçalves MLC, Araújo A, Sardella NH, Denegri GM 2008b. Capillaria spp eggs in Patagonian archaeological sites: statistical analysis of morphometric data. Mem Inst Oswaldo Cruz 103: 104-105.

Goñi R 1995. Aleros: uso actual e implicancias arqueológicas. Cuad Inst Nac Antropol Pens Lat 16: 329-342.

Goñi R, Aschero CA, González MA 1994. Arqueología y paleoambientes en el Parque Nacional Perito Moreno (Patagonia, Argentina), XIII Nat Congr Chilean Archaeol, 11 pp.

Jouy-Avantin F 2003. A standarized method for the description and study of coprolites. J Archaeol Sci 30: 367-372.

Lutz A 1919. Schistosoma mansoni e a schistosomatose segundo observaçoes feitas no Brasil. Mem Inst Oswaldo Cruz 1: 121-155.

Mancini MV, Páez M, Prieto A R 2002. Cambios paleoambientales durante los últimos $700014 \mathrm{C}$ años en el ecotono bosque-estepa, 47-48 ${ }^{\circ}$ S, Santa Cruz, Argentina. Ameghiniana 39: 151-162.

Morand S, Krasnov B, Poulin R, Degen A 2006. Micromammals and macroparasites: who is who and how they interact? In $\mathrm{S}$ Morand, BR Krasnov, R Poulin, Micromammls and macroparasites. From evolutionary ecology to management, SpringerVerlag, Tokio, p. 3-9.

Moravec F 2000. Review of capillariid and trichosomoidid nematodes from mammals in the Czech Republic and the Slovak Republic. Acta Soc Zool Bohem 64: 271-304.

Moravec F 2001. Trichinelloid nematodes parasitic in cold-blooded vertebrates, Academia, Praha, $429 \mathrm{pp}$.

Morini EG, Boero JJ, Rodríguez A 1955. Parásitos inestinales en el "mara" (Dolichotis patagonum). Mis Est Patol Reg Arg 26: 83-89. 
Nolf LO 1932. Experimental studies on certain factors influencing the development and viability of the ova of Trichuris as compared with those of the human Ascaris. Am J Hyg 16: 288-232.

Pardiñas UFJ, Galliari CA 2001. Reithrodon auritus. Mammalian Species 664: 1-8.

Perkins SE, Cattadori I, Hudson PJ 2005. The role of mammals in emerging zoonoses. Mamm Stud 30: S67-S71.

Radman N, Venturini L, Denegri G. 1986. Comprobación experimental de la presencia en Argentina de Capillaria aerophila Creplin, 1839 (Nematoda-Capillariidae). Rev Iber Parasitol 46: 267-272.

Redford KH, Eisenberg JF 1992. Mammals of the neotropics. Vol. 2. The Southern Cone: Chile, Argentina, Uruguay, Paraguay, University of Chigago Press, Illinois, $440 \mathrm{pp}$.

Rego AA 1961. Revisão do gênero Monoecocestus Beddard, 1914 (Cestoda: Anoplocephalidae). Mem Inst Oswaldo Cruz 59: 325-354.

Rindel DD 2003. Patrones de procesamiento faunistico durante el Holoceno medio y tardio en el sitio Alero Destacamento Guardaparque (Parque Nacional Perito Moreno, Provincia de Santa Cruz, Argentina), Licenciature Thesis, Universidad Nacional de Buenos Aires, Buenos Aires, 174 pp.

Rindel DD 2008. Arqueología de momentos tardíos en el Noroeste de la Provincia de Santa Cruz (Argentina): una perspectiva faunistica, $\mathrm{PhD}$ Thesis, Universidad Nacional de Buenos Aires, Buenos Aires, 503 pp.

Robles MDR 2008. Nematodes Oxiuridae, Trichuridae y Capillariidae en roedores Akodontini (Cricetidae, Sigmodontinae) de la Cuenca del Plata (Argentina): su importancia en la interpretación de las relaciones parásito-hospedador-ambiente, $\mathrm{PhD}$ Thesis, Universidad Nacional de La Plata, La Plata, 257 pp.

Robles MDR, Navone GT 2006. Redescription of Trichuris laevitestis (Nematoda: Trichuridae) from Akodon azarae and Scapteromys aquaticus (Sigmodontinae: Cricetidae) in Buenos Aires Province, Argentina. J Parasitol 92: 1053-1057.

Robles MDR, Navone GT, Notarnicola J 2006. A new species of Trichuris (Nematoda: Trichuridae) from Phyllotini rodents in Argentina. J Parasitol 92: 100-104.
Rossin A, Malizia A 2005. Redescription of Trichuris pampeana Suriano and Navone, 1994 (Nematoda: Trichuridae) from the South American subterranean rodent Ctenomys talarum (Rodentia: Octodontidae). J Parasitol 91: 27-130.

Sardella NH, Fugassa MH 2009a. Parasites in rodent coprolites from the historical archaeological site Alero Mazquiarán, Chubut Province, Argentina. Mem Inst Oswaldo Cruz 104: 37-42.

Sardella NH, Fugassa MH 2009b. Paleoparasitological analysis of rodent coprolites in Holocenic samples from Patagonia, Argentina. J Parasitol 95: 646-651.

Singh S, Samantaray JC, Singh N, Das GB, Verma IC 1993. Trichuris vulpis infection in an Indian tribal population. $J$ Parasitol 79: 457-458.

Singleton GR, Spratt DM, Barker SC, Hodgson PF 1991. The geographic distribution and host range of Capillaria hepatica (Bancroft) (Nematoda) in Australia. Int J Parasitol 21: 945-957.

Stine S, Stine M 1990. A record from Lake Cardiel of climate change in southern South America. Nature 345: 705-708.

Suriano DM, Navone GT 1994. Three new species of the genus Trichuris Roederer, 1761 (Nematoda: Trichuridae) from Cricetidae and Octodontidae rodents in Argentina. Res Rev Parasitol 54: 39-46.

Sutton CA 1973. Un nuevo Eucestode parásito de Myocastor coypus bonariensis Commerson. Neotropica 19: 38-42.

Wickström LM, Haukisalmi V, Varis S, Hantula J, Henttonen H 2005. Molecular phylogeny and systematics of anoplocephalinae cestodes in rodents and lagomorphs. Syst Parasitol 62: 83-99.

Wong MS, Bundy DAP 1990. Quantitative assesment of contamination of soil by the eggs of Ascaris lumbricoides and Trichuris trichiura. Trans Royal Soc Trop Med Hyg 84: 567-570.

Zhu X, Spratt DM, Beveridge I, Haycock P, Gasser RB 2000. Mithochondrial DNA polymorphism within and among species of Capillaria sensu lato from Australian marsupials and rodents. Int $J$ Parasitol 30: 933-938. 